\title{
Project of Having Children: A Review of National and International Scientific Literature
}

\author{
Mariana Biffi ${ }^{1}$ \\ Tania Mara Marques Granato \\ Graduate Program in Psychology as a Profession and Science, Pontificia \\ Universidade Católica de Campinas, Campinas, SP, Brazil
}

\begin{abstract}
In Western societies, the theme about the project of having children has gained prominence due to the reduction in birth rate and the postponement of parenthood, which has caused social, political and economic repercussions, as well as implications for the physical and mental health. In this context, this study aimed to comprehend how the project of having children or not has been investigated in the national and international scientific literature. We carried out a systematic review for the period 2009 to 2014, with 18 articles being selected. The studies analyzed indicate a choice between having children or not; the entry of the male figure into this area; the establishment of preconditions that make up the right time to have children; and conflicts that permeate this process of choice. The international studies focus on the process of choice and aimed to promote public polices, while the national researchers sought to understand recent phenomena such as the option not to have children. Therefore, we emphasize the relevance of the theme and the need for studies in the national context, search for new meanings that emerge from marital and family relationships.
\end{abstract}

Keywords: Parenthood, conjugality, contemporaneity, literature review.

\section{Projeto de Ter Filhos: Uma Revisão da Literatura Científica Nacional e Internacional}

\section{Resumo}

Nas sociedades ocidentais, o tema do projeto de ter filhos tem ganhado destaque devido à redução das taxas de natalidade e o adiamento da parentalidade, o que tem trazido repercussões sociais, políticas e econômicas, além de implicações para o âmbito da saúde física e mental. Nesse contexto, buscamos compreender como o projeto de ter ou não filhos vem sendo investigado na literatura científica nacional e internacional. Por meio de uma revisão sistemática realizada no período de 2009 a 2014, foram selecionados 18 artigos. Os estudos analisados indicam a possibilidade de escolha entre ter ou não filhos; a entrada da figura masculina nesse âmbito; o estabelecimento de pré-condições que configuram o momento certo para ter filhos; além dos conflitos e ambivalências que permeiam esse processo de escolha. Observamos que os estudos internacionais focalizam a tomada de decisão dos indivíduos e visam a promoção de políticas públicas, enquanto os trabalhos nacionais buscam compreender fenômenos recentes, como a opção de não ter filhos. Destaca-se assim, a relevância do tema e a necessidade de sua

Mailing address: Avenida Abdo Najar, 1221, Apto. 24, Americana, SP, Brazil 13466-615. E-mail: biffi. mariana@gmail.com

The present study was developed with support from the National Council for Scientific and Technological Development (CNPq). 
exploração no âmbito da pesquisa nacional, em busca da apreensão dos novos sentidos que emergem do relacionamento conjugal e familiar.

Palavras-chave: Parentalidade, conjugalidade, contemporaneidade, revisão de literatura.

\section{Los Planes de Tener Hijos: Una Revisión de la Literatura Científica Nacional e Internacional}

\section{Resumen}

En las sociedades occidentales, el tema de tener hijos há ganado atención debido a las tasas de natalidad más bajas y el postergación de la parentalidad, que ha traído repercusiones sociales, políticas y económicas, así como las implicaciones para el ámbito de la salud física y mental. En este contexto, se busca entender cómo los planes para tener hijos o no se investigan en la literatura científica nacional e internacional. A través de una revisión sistemática realizada de 2009 a 2014, se seleccionaron 18 artículos. Los estudios analizados indican la posibilidad de elegir entre tener hijos o no; la entrada de la figura masculina en esta área; el establecimiento de condiciones previas que integran el momento adecuado para tener hijos; además de los conflictos que atraviesan este proceso de elección. Observamos que los estudios internacionales centran se en el proceso de elección y son destinadas a la promoción de políticas públicas, mientras que los esfuerzos nacionales tratan de comprender los fenómenos recientes, como la decisión de no tener hijos. Cabe destacar de esta manera la importancia de la cuestión y su explotación en la pesquisa nacional, en busca de los nuevos significados que emergen de las relaciones matrimoniales y familiares.

Palabras clave: Parentalidad, matrimonio, contemporaneidad, revisión de literatura.

In the last fifty years, Western societies have seen a steady decline in birth rates, an increase in the age at which men and women have their first child and a growing number of marriages and divorces (Badinter, 2011). This condition has various social implications, affecting the social protection and health systems, indicating transformations in marital and family life (Brazilian Institute of Geography and Statistics, 2012). While these changes in reproductive patterns have initially taken place in developed countries, they follow the same trend in the Brazilian context, which indicates the need to comprehend the elements that participate in the contemporary choice between having children or not.

The possibility of choice regarding parenthood refers to a contemporary phenomenon that was consolidated during the twentieth century, as highlighted by Scavone (2001) when investigating the reflective dimension that began to permeate this decision. In agreement with the arguments of the author, we highlight that having children or not becomes a decision influenced by the subjective, biological, economic and social conditions of the couple. In addition, the greater the possibility of access to information and expertise, the greater the reflection before making a decision.

It is in this context of parenthood by choice that we see the emergence of a less standardized and more personalized life project, differing from the previous traditional model, in which marriage and children were included in any stable loving relationship (Borges \& Magalhães, 2013; Furstenberg, 2010). Thus, a model of union is currently consolidated in which the equal relationship between partners, the valorization of companionship in the marriage bond and the absence of reproduction obligations predominate (Merli, 2012).

Barbosa and Rocha-Coutinho (2012) recognize that we live in a time of transition in which the old models coexist with the new roles that become part of everyday life. This process culminates in a paradoxical experience for couples who are faced with the demands 
of contemporary living, as this prioritizes individualistic values, such as autonomy and professional development, while simultaneously emphasizes the importance of conjugality and the development of ideas and projects in common (Neves, Dias, \& Paravidini, 2013).

Rios and Gomes (2009a) indicate, from their literature review regarding the option not to have children, the importance that the dimension of the choice takes in the lives of contemporary couples. The authors highlight that this dimension is related to various aspects of life, not only parenting issues and that being able to choose constitutes a source of personal and marital satisfaction. However, the authors also refer to conflicts and distress that can accompany the decision making process, especially when there is prejudice against childless couples.

These matters converge, for Nunes (2011), in the ideal of the "contemporary woman", insofar as this remains tied to motherhood, producing intense suffering in women seeking to combine family and professional life. Such a scenario may lead to the choice of late motherhood, a process that can be accompanied by intense ambivalence, because of the difficulty of reconciling the maternal role with the roles that are already structured (Cooke, Mills, \& Lavender, 2010; Travassos-Rodriguez \& Féres-Carneiro, 2013).

Being a recent phenomenon, especially in the Brazilian context, Rios and Gomes (2009a) emphasize that the choice not to have children is still a little studied topic, which explains the predominance of international articles, due to the fact that European countries have been undergoing such transformations for longer. According to the authors, the aging of the population and decline in birth rates are issues that indicate, in the current scenario, the need for new social policies, in addition to the production of scientific knowledge to promote a comprehension more in tune with the contemporary issues.

Given the social relevance of the theme, and our intention to stimulate national scientific production, we proposed this study with the aim of comprehending how the project of having children or not is being investigated in the national and international literature. We understand the project of having children or not as the reflective dimension of the process of conjugal choice in the field of parenthood, the constituent elements of which refer to the biological, psychological and social.

\section{Methodological Strategies}

To organize the literature consulted, we developed a systematic review, as this method enables the critical evaluation and synthesis of the focused theme, provides access to the knowledge produced and deepens the issues (Mendes, Silveira, \& Galvão, 2008). The search for articles was carried out in the Scientific Electronic Library Online Brasil (SciELO Brasil), Scientific Electronic Library Online Regional (SciELO Regional), Periódicos em Psicologia (PePSIC), Literatura Latino Americana e do Caribe de Ciências da Saúde (LILACS), PsycINFO and Academic Search Premier databases, aiming to ensure coverage of national and international researches.

In the SciELO Brasil, SciELO Regional, LILACS and PePSIC indexing databases, four separate searches were performed, combining the keywords marriage and couple with the keywords children and parenthood (marriage AND children; marriage AND parenthood; couple AND children; couple AND parenthood). We adopted generic terms for this search considering that the national literature does not have specific terms for the investigated issue, in addition to the fact that this procedure would increase the number of studies found. This was corroborated by the results obtained by Rios and Gomes (2009a) who, when conducting a systematic review related to choosing not to have children, were also faced with the absence of specialized descriptors in the national literature.

In the PsycINFO and Academic Search Premier databases, two searches were conducted combining the descriptor decision making with the keywords parenthood and childbearing (decision making AND parenthood; decision making AND childbearing), which showed that the international literature has more specific terms. 
The inclusion criteria were that the empirical articles were indexed, written in Portuguese, Spanish or English, and met the objectives of the review (i.e., addressed the theme of the project of having children or not, exclusively in heterosexual men and women). We decided that the inclusion of different family configurations, such as homosexual, single-parent or recomposed families, would overly broaden the focus of this review, as these issues already delimit their own research area and, therefore, deserve a separate study.

In order to select the most recent publications related to the project of having children, works published in the previous five years were consider as the object of this review, understanding that this would reflect the panorama of contemporary research. Thus, searches of databases were carried out stipulating a period from January 2009 to May 2014. Recent publications were favored, with no restrictions established regarding the methodological design, theoreti- cal approach or area of knowledge in which the study was developed, including publications from various fields, such as psychology, anthropology, economics and nursing.

Regarding exclusion criteria, theoretical articles or literature reviews, book chapters, book reviews, dissertations and theses were discarded. Also we excluded articles that departed from the topic or that had very specific themes, such as the decision to have children in contexts of diseases such as cancer and HIV-AIDS, homosexual relationships, or in cases of sterility.

After conducting the search, we obtained a total of 372 items, however, after unifying the research results and excluding items that were repeated, we obtained a total of 243 publications. We read the titles and abstracts of the 243 articles and selected those that were in line with the guiding question of this study, namely that related to the project of having children in the present day. From this procedure, presented in Figure 1, we obtained a total of 18 articles that were included in the corpus of this review

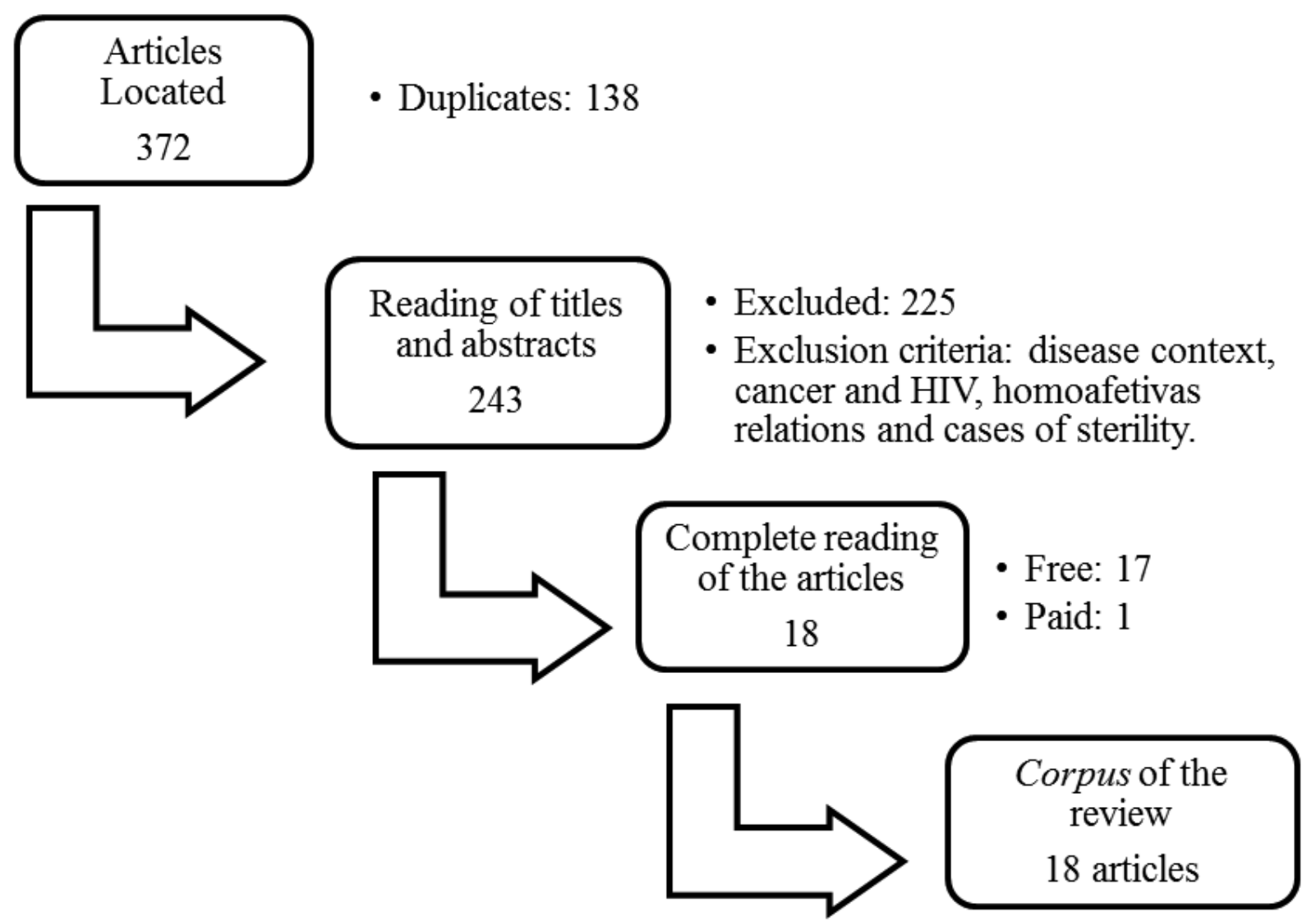

Figure 1. Steps of the systematic review. 
In the following step, we performed a complete reading of each work, preparing a summary of key information, such as the aims, participants, methodology, and results, summarizing these points in tables in order to facilitate the visualization of the findings. The findings of this study were discussed with other researchers from our research group, meeting the demand of triangulation, proposed by Stake (2011) as a procedure that increases the reliability of qualitative research, ensuring the validity of the extracted data and the consistency of the results.

\section{Results}

This review consisted of 18 articles, four national and 14 international, published in journals of different areas of knowledge. Half of the selected studies were interdisciplinary, while the other half distributed in specific disciplines such as Anthropology, Economics, Nursing and Psychology. We also point out that, in the national literature, most of the selected articles were found in journals of the psychology field, while the international articles were published in interdisciplinary journals.

Regarding the design of the studies, 10 adopted quantitative methods, while eight were qualitative studies. In relation to the country of origin, four studies were conducted in Brazil, two each in Australia, Canada, Portugal and Sweden and one in each of the following countries: South Africa, Hungary, England and Italy.

The methodological characteristics (design, participants, collection procedure, recording and analysis of the data) of the national studies are presented in Table 1 and those of the international studies in Table 2.

Table 1

Categorization of the National Articles Recovered in Terms of Design, Participants, Collection Procedure, Recording and Analysis of the Data (n=4)

\begin{tabular}{|c|c|c|c|c|c|}
\hline Article & Design & Participants & $\begin{array}{l}\text { Collection } \\
\text { procedure }\end{array}$ & $\begin{array}{l}\text { Registration } \\
\text { procedure }\end{array}$ & Data analysis \\
\hline $\begin{array}{l}\text { 1. Borges \& } \\
\text { Magalhães } \\
\text { 2. (2013) }\end{array}$ & Qualitative & $\begin{array}{l}10 \text { men and } 10 \\
\text { women, divided } \\
\text { into two groups } \\
\text { (27-34 and } \\
63-69 \text { years) }\end{array}$ & $\begin{array}{l}\text { Semi-structured } \\
\text { interviews }\end{array}$ & $\begin{array}{l}\text { Transcripts } \\
\text { of audio } \\
\text { recordings }\end{array}$ & $\begin{array}{l}\text { Discourse } \\
\text { analysis }\end{array}$ \\
\hline $\begin{array}{l}\text { 2. Rios \& Gomes } \\
(2009 b)\end{array}$ & Qualitative & $\begin{array}{l}\text { Four heterosexual } \\
\text { middle or upper class } \\
\text { couples, childless } \\
\text { by choice and aged } \\
\text { over } 35 \text { years }\end{array}$ & $\begin{array}{l}\text { Semi-structured } \\
\text { interviews }\end{array}$ & $\begin{array}{l}\text { Transcripts } \\
\text { of audio } \\
\text { recordings }\end{array}$ & $\begin{array}{c}\text { Categorization } \\
\text { of emerging } \\
\text { topics }\end{array}$ \\
\hline $\begin{array}{l}\text { 3. Silva et al. } \\
(2013)\end{array}$ & Qualitative & $\begin{array}{l}\text { Eight female users of a } \\
\text { Primary Health Unit }\end{array}$ & $\begin{array}{l}\text { Semi-structured } \\
\text { interviews }\end{array}$ & $\begin{array}{l}\text { Transcripts } \\
\text { of audio } \\
\text { recordings }\end{array}$ & $\begin{array}{l}\text { Thematic } \\
\text { content } \\
\text { analysis }\end{array}$ \\
\hline $\begin{array}{l}\text { 4. Sohne \& Wendling } \\
\text { (2011) }\end{array}$ & Qualitative & $\begin{array}{l}\text { Three couples, aged } \\
\text { between } 35 \text { and } 41 \\
\text { years, who chose } \\
\text { not to have } \\
\text { children }\end{array}$ & $\begin{array}{l}\text { Semi-structured } \\
\text { interviews }\end{array}$ & $\begin{array}{l}\text { Transcripts } \\
\text { of audio } \\
\text { recordings }\end{array}$ & $\begin{array}{l}\text { Content } \\
\text { analysis }\end{array}$ \\
\hline
\end{tabular}


Table 2

Categorization of the International Articles Recovered in Terms of Design, Participants, Collection Procedure, Recording and Analysis of the Data (n=14)

\begin{tabular}{|c|c|c|c|c|c|}
\hline Article & Design & Participants & $\begin{array}{l}\text { Collection } \\
\text { procedure }\end{array}$ & $\begin{array}{l}\text { Registration } \\
\text { procedure }\end{array}$ & $\begin{array}{c}\text { Data } \\
\text { analysis }\end{array}$ \\
\hline $\begin{array}{l}\text { 1. Gauthier \& } \\
\text { deMontigny (2013) }\end{array}$ & Qualitative & $\begin{array}{l}12 \text { men, first time } \\
\text { fathers, aged } 21-35 \\
\text { years }\end{array}$ & $\begin{array}{l}\text { Semi-structured } \\
\text { interviews }\end{array}$ & $\begin{array}{l}\text { Transcripts } \\
\text { of audio } \\
\text { recordings }\end{array}$ & $\begin{array}{l}\text { Thematic } \\
\text { analysis }\end{array}$ \\
\hline $\begin{array}{l}\text { 2. Guedes, Pereira, } \\
\text { Pires, Carvalho, \& } \\
\text { Canavarro (2013) }\end{array}$ & Quantitative & $\begin{array}{l}614 \text { individuals } \\
\text { aged between } 19 \\
\text { and } 49 \text { years }\end{array}$ & Scale & Self report & $\begin{array}{l}\text { Statistical } \\
\text { procedures }\end{array}$ \\
\hline $\begin{array}{l}\text { 3. Hollos \& Bernardi } \\
\text { (2009) }\end{array}$ & Qualitative & $\begin{array}{l}19 \text { couples aged } \\
\text { between } 20 \\
\text { and } 42 \text { years }\end{array}$ & $\begin{array}{l}\text { Semi-structured } \\
\text { interviews }\end{array}$ & $\begin{array}{l}\text { Transcripts } \\
\text { of audio } \\
\text { recordings }\end{array}$ & $\begin{array}{l}\text { Thematic } \\
\text { analysis }\end{array}$ \\
\hline $\begin{array}{l}\text { 4. Holton, Fisher, } \\
\text { \& Rowe (2009) }\end{array}$ & Quantitative & $\begin{array}{c}569 \text { women } \\
\text { aged between } \\
30 \text { and } 34 \text { years }\end{array}$ & $\begin{array}{c}\text { Closed } \\
\text { questionnaires }\end{array}$ & Self report & $\begin{array}{l}\text { Statistical } \\
\text { procedures }\end{array}$ \\
\hline $\begin{array}{l}\text { 5. Hutteman, } \\
\text { Bleidorn, Penke, } \\
\& \text { Denissen (2013) }\end{array}$ & Quantitative & $\begin{array}{c}2482 \text { couples } \\
\text { biologically capable } \\
\text { of having children }\end{array}$ & $\begin{array}{l}\text { Population } \\
\text { survey data }\end{array}$ & - & $\begin{array}{l}\text { Statistical } \\
\text { procedures }\end{array}$ \\
\hline $\begin{array}{l}\text { 6. Iacovou \& } \\
\text { Tavares (2011) }\end{array}$ & Quantitative & & $\begin{array}{l}\text { Population } \\
\text { survey data }\end{array}$ & $\longrightarrow$ & $\begin{array}{l}\text { Statistical } \\
\text { procedures }\end{array}$ \\
\hline $\begin{array}{l}\text { 7. Kaufman \& } \\
\text { Bernhardt (2012) }\end{array}$ & Quantitative & $\begin{array}{l}650 \text { heterosexual and } \\
\text { childless individuals }\end{array}$ & $\begin{array}{l}\text { Population } \\
\text { survey data }\end{array}$ & - & $\begin{array}{l}\text { Statistical } \\
\text { procedures }\end{array}$ \\
\hline $\begin{array}{l}\text { 8. Matias } \\
\& \text { Fontaine (2013) }\end{array}$ & Quantitative & $\begin{array}{l}403 \text { individuals with } \\
\text { mean age of } 36 \text { years }\end{array}$ & Scale & Self report & $\begin{array}{l}\text { Statistical } \\
\text { procedures }\end{array}$ \\
\hline 9. Morison (2013) & Qualitative & $\begin{array}{c}12 \text { men and } 11 \text { women, } \\
\text { heterosexual } \\
\text { and middle class }\end{array}$ & $\begin{array}{l}\text { Semi-structured } \\
\text { interviews }\end{array}$ & Not specified & $\begin{array}{l}\text { Discursive- } \\
\text { narrative } \\
\text { method }\end{array}$ \\
\hline 10. Öst (2012) & Quantitative & $\begin{array}{l}\text { 2,059 subjects, } \\
\text { divided into three } \\
\text { groups according } \\
\text { to birth date (1956, } \\
1964 \text { and } 1974)\end{array}$ & $\begin{array}{l}\text { Population } \\
\text { survey data }\end{array}$ & - & $\begin{array}{l}\text { Statistical } \\
\text { procedures }\end{array}$ \\
\hline $\begin{array}{l}\text { 11. Pinquart, } \\
\text { Stotzka, \& } \\
\text { Silbereisen (2010) }\end{array}$ & Quantitative & $\begin{array}{l}267 \text { young adults } \\
\text { aged } 25-30 \text { years }\end{array}$ & $\begin{array}{c}\text { Closed } \\
\text { questionnaire }\end{array}$ & Self report & $\begin{array}{l}\text { Statistical } \\
\text { procedures }\end{array}$ \\
\hline $\begin{array}{l}\text { 12. Roberts, } \\
\text { Metcalfe, Jack, } \\
\text { \& Tough }(2011)\end{array}$ & Quantitative & $\begin{array}{l}495 \text { men aged } 20 \\
\text { to } 45 \text { years without } \\
\text { biological children } \\
\text { divided into four } \\
\text { groups according } \\
\text { to age }\end{array}$ & $\begin{array}{c}\text { Closed } \\
\text { questionnaire }\end{array}$ & $\begin{array}{l}\text { Fill by } \\
\text { researchers } \\
\text { (study } \\
\text { conducted } \\
\text { by telephone } \\
\text { contact) }\end{array}$ & $\begin{array}{l}\text { Statistical } \\
\text { procedures }\end{array}$ \\
\hline $\begin{array}{l}\text { 13. Testa, Cavalli, } \\
\text { \& Rosina (2014) }\end{array}$ & Quantitative & $\begin{array}{l}2.098 \text { couples } \\
\text { aged between } \\
18 \text { and } 49 \text { years }\end{array}$ & $\begin{array}{l}\text { Population } \\
\text { survey data }\end{array}$ & - & $\begin{array}{l}\text { Statistical } \\
\text { procedures }\end{array}$ \\
\hline $\begin{array}{l}\text { 14. Thompson, Lee, } \\
\text { \& Adams (2013) }\end{array}$ & Qualitative & $\begin{array}{c}16 \text { male university } \\
\text { students, aged } 18-25 \\
\text { years, unmarried and } \\
\text { without children }\end{array}$ & $\begin{array}{l}\text { Semi-structured } \\
\text { interviews }\end{array}$ & $\begin{array}{l}\text { Transcripts } \\
\text { of audio } \\
\text { recordings }\end{array}$ & $\begin{array}{l}\text { Thematic } \\
\text { analysis }\end{array}$ \\
\hline
\end{tabular}


We observed that in the national studies, only qualitative studies were identified, with no quantitative studies being found. In the qualitative studies, the semi-structured interview was used as the standard procedure in all cases, as well as discourse analysis as the data analysis method, although they were guided by different theoretical frameworks.

In the case of the international studies, we found a prevalence of quantitative studies (77.8\%), with population survey data being used in half the cases (Hutteman et al., 2013; Iacovou
\& Tavares, 2011; Kaufman \& Bernhardt, 2012; Öst, 2012; Testa et al., 2014). In all the quantitative studies, data were produced from questionnaires or scales, with statistical procedures used for the data analysis.

In the international qualitative studies $(22,2 \%)$, we observed the same trend as in the national studies, with the semi-structured interview the only procedure adopted and discourse analysis used as the data analysis method.

The aims and results of the studies that compose this review are summarized in Tables 3 and 4.

Table 3

Aims and Main Results of the National Studies Retrieved (n=4)

\begin{tabular}{|c|c|c|}
\hline Article & Aims & Main results \\
\hline 1 & $\begin{array}{l}\text { To analyze the life projects of } \\
\text { individuals of different generations, } \\
\text { giving emphasis to the place } \\
\text { raising a family had in their plans. }\end{array}$ & $\begin{array}{l}\text { Removal of the pattern of life trajectories and disintegration } \\
\text { of the family model based on marriage when the discourse } \\
\text { of the two groups was compared. Children become individual } \\
\text { projects and have central importance for the family idea. }\end{array}$ \\
\hline 2 & $\begin{array}{l}\text { To reflect about the stigma and } \\
\text { conjugality present in the option } \\
\text { of couples not to have children. }\end{array}$ & $\begin{array}{l}\text { The stigmatization felt by the participants seems to reflect the } \\
\text { continuing difficulty in living with the various forms of family, } \\
\text { which produces a greater need for repairs or the presence } \\
\text { of some reactive forces of defense in the couples. }\end{array}$ \\
\hline 3 & $\begin{array}{l}\text { To describe how women } \\
\text { perceive the participation } \\
\text { of the partner in family planning. }\end{array}$ & $\begin{array}{l}\text { Emergence of two main categories: the first refers to the agreement } \\
\text { reached by the couple over when to have children and the second to } \\
\text { the responsibility of women regarding the contraception. }\end{array}$ \\
\hline 4 & $\begin{array}{l}\text { To investigate the meaning of } \\
\text { family for couples who choose not } \\
\text { to have children, as well as analyze } \\
\text { the social influence and that of the } \\
\text { family of original faced with this. }\end{array}$ & $\begin{array}{l}\text { The meaning of family was shown to be permeated } \\
\text { with differences, since some of the participants considered } \\
\text { that to be a couple was enough, while for others there was } \\
\text { a need for children. }\end{array}$ \\
\hline
\end{tabular}


Table 4

Aims and Main Results of the International Studies Retrieved (n=14)

\begin{tabular}{cc}
\hline Article & Aims \\
\hline $1 \quad$ & $\begin{array}{c}\text { To describe the elements that contribute } \\
\text { to the decision of having the first } \\
\text { child for men. }\end{array}$ \\
& To construct the final version \\
of the Childbearing Motivations \\
Scale (CMS) and to examine \\
its factor structure and psychometric \\
properties.
\end{tabular}

To investigate the associations between the personality of the partners, expectations and parenthood intentions and the fertility results of the couple one year later.

To examine the effects of the characteristics of individuals and their partners in adjusting expectations regarding fertility.

To examine the relationship between organizational culture and fertility plans in Sweden.

To describe the construction and validation of an instrument in English for analysis of the reasons underlying the decision to have children or not.

To investigate the involvement of the South

9 African heterosexual man in the process of decision to become a parent.

To contribute to the comprehension of the correlation between home ownership and becoming a parent, considering the potential between these two events.

To evaluate the ambivalence involved in the conflict approach/hesitation between wanting to have children or not.

To describe the factors that influence the intention of men to become fathers and describe the differences between the age groups studied.

To investigate the process of choice about having children, especially with regard to gender equality.

To explore the subjective meaning
The elements that contribute to the decision relate to four main areas: personal, socioeconomic, interpersonal and temporal characteristics.

Final version of the CMS was composed of 26 positive motivations (socioeconomic aspects, personal fulfillment, continuity and relationship of the couple) and 21 negative motivations (demands of parenthood, social concern, stress in the relationship).

The couples emphasized the importance of a series of requirements, such as financial security and a good marital relationship, to have children.

Employment, education level and religion were the sociodemographic factors that significantly related to the attitudes of women in relation to maternity.

Low levels of negative expectations were associated with high intention to become a father in the following two years, while the positive expectations seemed to have no influence.

Presence or absence of partner was not characterized as a significant factor. Among the participants with partners, it was observed that these plans consider the partner in the decision process.

Men seemed to have more intention to have children if the work of the partner facilitates access to maternity leave and to part-time job. While women showed greater intentions when the partner was well paid.

The final version of the scale consists of 30 items that refer to reasons to have children or not, relating to four factors: emotional enrichment, social recognition, interference in lifestyle and difficulties in the education of the child.

Importance of including the male figure, who showed a passive role in the decisions of the couple.

The results indicated a correlation between the two events, especially for the two younger groups. Owning a house was shown to be a condition for having children.

Minority of the participants proved ambivalent about the subject. Factors related to ambivalence seemed to be: the divergence between the goals related to parenthood and other objectives, the high cost involved and also the indecision of the partner

Factors such as financial security, adequacy and partner interest in having children were elements that influence the four groups surveyed. Biological issues were relevant only for the older men.

The results did not indicate the existence of equality in the process of choosing whether to have children. The hypothesis that women would be more influential in decision-making was not confirmed.

The participants considered becoming a father to be fundamental for future happiness. They showed themselves to be involved in the conflict of having children at a certain age or under certain conditions and also in reconciling models of traditional and modern parenthood. 


\section{Discussion}

Based on the indicated results, we summarize the main findings into four categories: Having children or not: a process of choice; Transition to parenthood: a conjugal project; Right time to have a child; and Conflicts related to the choice between having children or not.

\section{Having Children or Not: A Process of Choice}

Several authors discuss the dimension of choice, indicating its implications in both the family and social contexts (Borges \& Magalhães, 2013; Morison, 2013; Rios \& Gomes, 2009b). The possibility of choosing seems to be consolidated as an important aspect of contemporary marital life, an issue already highlighted by Rios and Gomes (2009a), although new problems arise, such as late motherhood and the stigmatization of couples who chose not to have children, who start to figure as the object of new studies (Holton et al., 2009; Sohne \& Wedling, 2011).

Borges and Magalhães (2013) highlighted the emergence of a new concept of family centered on the project of having children, and no longer within a marriage. According to the authors, such a change appears to reduce the asymmetry between genders, with the female discourse approaching that of the male, in that the focus on professional development and financial independence is maintained, surpassing the woman-mother and man-provider dichotomy.

Although the new social context allows multiple family configurations, Morison (2013) points out that the persistence of heteronormative beliefs may compromise the reflection prior to making a decision on whether or not to have children, leading to a naturalization of parenthood.

The studies that highlight the prejudice against couples who decide not to have children suggest that this kind of choice is still in a process of consolidation, especially in the national scenario (Rios \& Gomes, 2009a). Despite the transformations, social expectations that couples opt to have children appear to prevail, which seems like resistance to the multiplicity of arrangements that are outlined, as indicated Rios and Gomes (2009b).

The relationship between choice and postponement of parenthood is another point explored by the researchers, due to the establishment of life projects solely aimed at professional development and financial independence (Holton et al., 2009). In agreement with the findings of the literature review made by Cooke et al. (2010), the postponement of parenthood manifested as an informed choice is actually uninformed, in that the limits and risks posed by a late pregnancy are neglected.

Considering the implications of contemporary fertility patterns for the economy and health, some researchers developed psychometric instruments aimed at understanding the elements involved in the process of choice for couples (Guedes et al., 2013; Matias \& Fontaine; 2013). Factors such as emotional exchange, personal development, transmission of heritage and social recognition appear to contribute to the decision to have children, while the responsibilities of the parental exercise, financial problems, difficulties in the education of children and the psychological distress of pregnancy are associated with choosing not to have children.

\section{Transition to Parenthood: A Conjugal Project}

The selected studies show the importance of including the male vision in the process of choice, decentralizing it from the female figure, as we traditionally observe (Gauthier \& deMontigny, 2013; Roberts et al., 2011). Thus, a new dynamic characterizes the marital relationship between men and women who find themselves called upon to reflect and make a decision about future parenthood (Scavone, 2001).

Testa et al. (2014) conclude that there is no equality of power between men and women in making a decision to have children, however, the hypothesis that women predominantly act on this issue was not proven. The authors explain that, since parenthood has implications for both, it is necessary to establish an agreement between 
the partners, however, the companion that wants to have more children seems to have more influence in the selection process.

The findings of Iacovou and Tavares (2011) follow in the same direction when they indicate that individuals consider the plans of their partners when they plan to have a child. Hutteman et al. (2013) confirm that the planning of the first child is performed by the couple; however, from the second child, the intention of the woman acts as the decisive factor.

In this scenario, where men and women are invited to reflect on parenthood, before making a decision, Kaufman and Bernhardt (2012) point out that the working conditions of the couple can influence their projects, this being a factor considered by both partners. According to the authors, men with jobs that enable paternity leave and those that work part-time, express a greater intention to have children, as do women who benefit from maternity leave.

Unlike the studies which refer to the European context, Silva et al. (2013), analyzing family planning in the Brazilian context, highlight the existence of an agreement between the partners on when to have children, which would indicate joint planning; however, contraception is still the responsibility of the woman. The authors indicate that the participation of the man in the context of sexual and reproductive care in Brazil is still incipient, which indicates the need for health professionals to consider the couple, not just the woman, as a care unit.

Despite the differences found in the national and international literature, we observed that male participation has frequently been stimulated by the social debate on parenthood and childcare. This behavior breaks with a tradition that delegated these tasks to the woman, to include the man as a subject of rights and duties.

\section{Right Time to Have a Child}

Some of the studies sought to identify the elements that indicate the right time to have children for couples, such as the work of Cooke et al. (2010), Gauthier and deMontigny (2013), Hollos and Bernardi (2009), Öst (2012), Roberts et al. (2011) and Thompson et al. (2013).
The prerequisites identified by the men refer to personal, such as the desire to have children and start a family; interpersonal, associated with the influence of the partner and social context; socioeconomic, related to personal stability and home ownership and, finally, temporal characteristics, related to biological issues and personal maturity (Gauthier \& deMontigny, 2013; Roberts et al., 2011; Thompson et al., 2013). It should be noted that considerations related to biological aspects seem to be more relevant for older men, as highlighted by Roberts et al. (2011).

Amid a broad set of preconditions, Thompson et al. (2013) emphasize the emergence of conflict between having children in certain conditions or at a certain age, since the consideration of all factors would lead to delaying parenthood until these objectives were achieved. The authors also emphasize that men are faced with conflicting models of fatherhood, as the traditional father vision as financial provider coexists with the contemporary ideal of a father more participatory and involved in raising the children.

When interviewing couples, Hollos and Bernardi (2009) identified similar criteria to those mentioned above, such as a stable income, financial security, good relationship with the partner, stable partnership and access to childcare. Although the satisfaction of all of these conditions leads to late parenthood, nonchalance appears to persist regarding the biological questions, as pointed out in the literature review carried out by Cooke et al. (2010).

From the analysis of the studies, we observed that the incorporation of the values of capitalism in affective relationships appears to contribute to the view that there is a right time to have children. This can lead to the idealization of the parental experience and consequent frustration of expectations (Neves et al., 2013; Nunes, 2011; Travassos-Rodriguez \& FéresCarneiro, 2013). In addition, the implications of late parenthood, such as the need for assisted reproduction, with its share of suffering and high financial costs, seem to be ignored by couples who assume control over the biological issues, in the same way that they control their lives (Cooke et al., 2010). 


\section{Conflicts Related to the Choice of Having Children or Not}

When investigating the conjugal choice not to have children, Rios and Gomes (2009b) highlighted that the way each couple deals with this choice relates to the level of ambivalence and conflict during the process, as well as type of bond established. According to the authors, in the cases where ambivalence is higher, there may be a greater need for repair or other form of defense to cope with the stigmatization and prejudice that still exist.

The study by Pinquart et al. (2010) refers to a predominance of ambivalence when the conflict between parenthood and other goals is influenced by the high financial cost involved, as well as the indecision of the partners. The authors add that women tend to be more ambivalent than men, and that they aim to have more children than men.

These issues confirm the findings of Travassos-Rodriguez and Féres-Carneiro (2013) regarding the impossibility of expression of maternal ambivalence in contemporary society, when presented with the current maternal and professional ideals. In the direction of the arguments of Nunes (2011), we highlight the ideal of the "contemporary women" that combines professional development with motherhood, as a generator of feelings of guilt, when proposing a model that ignores the personal needs.

\section{Final Considerations}

From this literature review, we identified four key issues that permeate the theme of the project of having children or not: the process of choosing between having children or not, the transition to parenthood as a conjugal project, the right time to have a child, and the conflicts that pervade the process of choosing. Scientific studies highlight the complexity of this conjugal course, the emergence and growing visibility of which indicates the relevance of its study. The comprehension of the contemporary reproductive patterns may subsidize both professional practices in health and public policies proposals to be more in tune with contemporary social demands.

The majority of the scientific literature on the investigated subject is international, an issue which may be related to the fact that European countries, as well as Australia and Canada, have been experiencing new conjugal and family configurations for longer than Brazil, as highlighted by Rios and Gomes (2009a). This experience with a greater diversity of reproductive patterns and their effects, such as an aging population, explains the fact that only the international studies manifest the intention that their results lead to the development of public policies to raise birthrates (Hutteman et al., 2013; Kaufman \& Bernhardt, 2012; Öst, 2012; Roberts et al., 2011).

This has implications that include the methodological choice of the studies, with the studies on the process of decision making being predominant in the international area (i.e., approaching the participants prior to their choice; Hollos \& Bernardi, 2009; Holton et al., 2009; Iacovou \& Tavares, 2011; Pinquart et al., 2010; Roberts et al., 2011; Testa et al., 2014; Thompson et al., 2013). In contrast, in the national studies the participants were approached after the decisionmaking, which can be explained by the fact that the new family arrangements, the option of not having children and postponing motherhood are still recent phenomena (Rios \& Gomes, 2009a, 2009b; Silva et al., 2013; Sohne \& Wendling, 2011).

Plenty of studies in the international context, as opposed to the incipient Brazilian production, indicate the need for empirical research at the national level to discuss the process of conjugal choice regarding having children or not. In the national scientific production, we identified the same shortcomings highlighted by Rios and Gomes (2009a): the paucity of Brazilian research related to the theme investigated, the concentration of studies in large urban centers and the unanimous adoption of qualitative designs.

Some limitations of this review study should be highlighted, these include the adoption of different descriptors for the national and 
international searches. Although strategic, due to lack of matching terms between languages, this can hinder the apprehension of the phenomenon, and the replicability of the study. Furthermore, the fact that we did not complement the initial search with the analysis of the publications contained in the bibliographic list of the selected articles may have prevented other eligible studies from being included in this review.

The results provide subsidies for clinical practice with couples and families, including that related to the development of preventive actions that can address issues such as ambivalence involved in the process of choosing and the implications of late parenthood. Furthermore, the growing visibility of the theme in the national context and its impact in the socio-political context, allow us to speculate on the role of knowledge production in promoting public policies that effectively meet the needs of families.

We hope this review study will encourage the production of knowledge related to the project of having children, enabling reflections on contemporary family demands and the deconstruction of stereotypes related to family models. In the context of Psychology, it is important to promote a critical comprehension of the process of becoming a father and mother, to break with the long tradition of focusing studies of childhood or family on the maternal figure.

We end this review suggesting new research objectives, such as conjugal development of the project of having children or not, the transformation of conjugality in the transition to parenthood, as well as the development of new study designs that include the male figure, explore new methodologies and expand study contexts beyond the major urban centers.

\section{References}

Badinter, E. (2011). O conflito: A mulher e a mãe. Rio de Janeiro, RJ: Record.

Barbosa, P. Z., \& Rocha-Coutinho, M. L. (2012). Ser mulher hoje: A visão de mulheres que não desejam ter filhos. Psicologia e Sociedade, 24(3), 577587. doi:10.1590/S0102-71822012000300011

Borges, C. C., \& Magalhães, A. S. (2013). Individualism, life trajectories and plans of con- stituting a family. Estudos de Psicologia (Campinas), 30(2), 177-185. doi:10.1590/ S0103-166X2013000200004

Brazilian Institute of Geography and Statistics. (2012). Censo Demográfico 2010: Nupcialidade, Fecundidade e Migração. Retrieved from http://censo2010.ibge.gov.br/

Cooke, A., Mills, T. A., \& Lavender, T. (2010). 'Informed and uninformed decision making' Women's reasoning, experiences and perceptions with regard to advanced maternal age and delayed childbearing: A meta-synthesis. International Journal of Nursing Studies, 47(10), 1317-1329. doi:10.1016/j.ijnurstu.2010.06.001

Furstenberg, F. F., Jr. (2010). On a new schedule: Transitions to adulthood and family change. The Future of Children, 20(1), 67-87. Retrieved from http://futureofchildren.org/futureofchildren/publications/docs/20_01_04.pdf

Gauthier, P., \& deMontigny, F. (2013). Conceiving a first child: Perceptions of contributing elements to their decision. Journal of Reproductive and Infant Psychology, 31(3), 274-284. doi:10.1080/ 02646838.2013 .809519

Guedes, M., Pereira, M., Pires, R., Carvalho, P., \& Canavarro, M. C. (2013). Childbearing Motivations Scale: Construction of a new measure and preliminary psychometric properties. Journal of Child and Family Studies, 1-15. doi:10.1007/ s10826-013-9824-0

Hollos, M., \& Bernardi, L. (2009). Post-Socialist Uncertainty: Childbearing decisions in Hungary. Ethnology, 48(4), 315-336. Retrieved from http://ethnology.pitt.edu/ojs/index.php/ Ethnology/article/view/6066/6258

Holton, S., Fisher, J., \& Rowe, H. (2009). Attitudes toward women and motherhood: Their role in Australian Women's Childbearing Behaviour. Sex Roles, 61(9-10), 677-687. doi:10.1007/ s11199-009-9659-8

Hutteman, R., Bleidorn, W., Penke, L., \& Denissen, J. J. A. (2013). It takes two: A longitudinal dyadic study on predictors of fertility outcomes. Journal of Personality, 81(5), 487-498. doi:10.1111/ jopy.12006

Iacovou, M., \& Tavares, L. P. (2011). Yearning, learning and conceding: Reasons men and women change their childbearing intentions. Population and Development Review, 37(1), 89123. doi:10.1111/j.1728-4457.2011.00391.x 
Kaufman, G., \& Bernhardt, E. (2012). His and her job: What matters most for fertility plans and actual childbearing?. Family Relations, 61(4), 686697. doi:10.1111/j.1741-3729.2012.00720.x

Matias, M., \& Fontaine, A. M. (2013). Desenvolvimento e Validação Factorial da Escala de Motivos face à Parentalidade. Paidéia (Ribeirão Preto), 23(54), 9-20. doi:10.1590/198243272354201303

Mendes, K. D. S., Silveira, R. C. C. P., \& Galvão, C. M. (2008). Revisão integrativa: Método de pesquisa para a incorporação de evidências na saúde e na enfermagem. Texto Contexto Enfermagem, 17(4), 758-764. doi:10.1590/S010407072008000400020

Merli, L. F. (2012). Quando a parentalidade surge antes da conjugalidade (Master's thesis, Universidade de São Paulo, SP, Brazil).

Neves, A. S., Dias, A. S. F., \& Paravidini, J. L. L. (2013). A psicodinâmica conjugal e a contemporaneidade. Psicologia Clinica, 25(2), 73-87. doi:10.1590/S0103 56652013000200005

Morison, T. (2013). Heterosexual men and parenthood decision making in South Africa: Attending to the invisible norm. Journal of Family Issues, 20(10), 1-20. doi:10.1177/0192513X13484271

Nunes, S. A. (2011). Afinal, o que querem as mulheres? Maternidade e mal-estar. Psicologia Clinica, 23(2), 101-115. doi:10.1590/S010356652011000200007

Öst, C. E. (2012). Housing and children: Simultâneos decisions?- A cohort study of young adults' housing and family formation decision. Journal of Population Economics, 25(1), 349-366. doi:10.1007/s00148-010-0345-5

Pinquart, M., Stotzka, C., \& Silbereisen, R. K. (2010). Ambivalence in decisions about childbearing. Journal of Reproductive and Infant Psychology, 28(2), 212-220. doi:10.1080/02646830903295034

Rios, M. G., \& Gomes, I. C. (2009a). Casamento contemporâneo: Revisão de literatura acerca da opção por não ter filhos. Estudos de Psicologia. (Campinas), 26(2), 215-225. doi:10.1590/ S0103-166X2009000200009

Rios, M. G., \& Gomes, I. C. (2009b). Estigmatização e conjugalidade em casais sem filhos por opção. Psicologia Estudos, 14(2), 311-319. doi:10.1590/S1413-73722009000200012
Roberts, E., Metcalfe, A., Jack, M., \& Tough, S. C. (2011). Factors that influence the childbearing intentions of Canadian men. Human Reproduction, 26(5), 1202-1208. doi:10.1093/humrep/ der007

Scavone, L. (2001). Maternidade: Transformações na família e nas relações de gênero. Interface - Comunicação, Saúde, Educação, 5(8), 47-59. Retrieved from http://www.scielo.br/ scielo.php?script $=$ sci_arttext\&pid $=$ S 1414$32832001000100004 \& \operatorname{lng}=\mathrm{en} \& \mathrm{t} \operatorname{lng}=\mathrm{pt}$

Silva, G. S., Landerlahl, M. C., Langerdorf, T. F., Padoin, S. M. M., Vieira, L. B., \& Anversa, E. T. R. (2013). Partner's participation in family planning from a feminine perspective: A descriptive study. Online Brazilian Journal of Nursing, 12(4), 882-891. doi:10.5935/16764285.20134224

Sohne, L. C., \& Wendling, M. I. (2011). O significado da família para casais que optam por não ter filhos. Pensando Famílias, 15(1), 117-137. Retrieved from http://domusterapia.com.br/site/ principal/revista nivel3 .asp? $\operatorname{codConteudo}=409$

Stake, R. (2011). Pesquisa Qualitativa: Estudando como as coisas funcionam. Porto Alegre, RS: Penso.

Testa, M. R., Cavalli, L., \& Rosina, A. (2014). The effect of couple disagreement about child-timing intentions: A parity-specific aproach. Population and Development Review, 40(1), 31-53. doi:10.1111/j.1728-4457.2014.00649.x

Thompson, R., Lee, C., \& Adams, J. (2013). Imagining fatherhood: Young Australian men's perspectives on fathering. International Journal of Men's Health, 12(2), 150-165. doi:10.3149/ jmh.1202.150

Travassos-Rodriguez, F., \& Féres-Carneiro, T. (2013). Maternidade e ambivalência: Algumas reflexões. Tempo Psicanalítico, 45(1), 111-121. Retrieved from http://pepsic.bvsalud.org/pdf/ tpsi/v45n1/v45n1a08.pdf 